\title{
Preparation of sucrose fatty acid esters as food emulsifiers and evaluation of their surface active and emulsification properties
}

\author{
By Mohamed G. Megahed \\ National Research Centre, Fats and Oils Department, Dokki, Cairo, Egypt.
}

\begin{abstract}
RESUMEN
Preparación de ésteres de ácidos grasos con sacarosa como emulsionantes alimentarios y evaluación de sus propiedades superficiales y emulsionantes.

Se ha llevado a cabo un método simple para la preparación de ésteres de sacarosa a partir de ácidos grasos y sacarosa de bajo coste. Se han usado ácidos laurico, palmítico y oleíco en su preparación, en ausencia de solventes orgánicos. Se obtuvieron rendimientos aceptables del $86.5 \%, 87.3 \%$ y $88.6 \%$ para los ésteres del laurico, palmítico y oleíco respectivamente.

En los productos se evaluaron sus balances hidrófilo-lipófilo (HLB), sus propiedades de tensión superficial e interfacial así como su estabilidad en emulsiones. Los resultados mostraron que estos ésteres de sacarosa exhíben propiedades similares a las de los compuestos preparados comercialmente.
\end{abstract}

PALABRAS-CLAVE: Emulsionante alimentario - Esteres de ácidos grasos con sacarosa - Propiedades emulsionantes - Propiedades superficiales.

\section{SUMMARY}

Preparation of sucrose fatty acid esters as food emulsifiers and evaluation of their surface active and emulsification properties.

A simple method for the preparation of sucrose esters, from fatty acids and the least expensive sucrose, has been conducted. Fatty acids namely lauric, palmitic and oleic were used in their preparation in the absence of any organic solvent. Reasonable yields amounting to $86.5 \%, 87.3 \%$ and $88.6 \%$ for sucrose esters of laurate, palmitate and oleate were obtained, respectively.

The products were evaluated for their hydrophile-lipophile balance (HLB), surface and interfacial tension properties as well as emulsion stability. The results showed that these sucrose esters exhibit similar properties as those of the commercially prepared compounds.

KEY-WORDS: Emulsification properties - Food emulsifier Sucrose fatty acid esters - Surface active properties.

\section{INTRODUCTION}

Emulsifiers are imported in tonnages for their use in foods, household detergents, cosmetic and phamaceutical products. Different methods of emulsifier preparation were conducted in the presence or absence of solvents. Toxic solvents were usually used for the preparation of these compounds (Weiss et al., 1971, 1972; Bobalek, 1977; Akoh and Swanson, 1987, 1989), however others excluded solvents in such preparation (Heesen et al., 1976; Rizzi and Taylor, 1978).

It was planned to use a simple method for preparation of emulsifiers from sucrose and different fatty acids (lauric, palmitic and oleic) aiming to develop and improve the method of the preparation of sucrose esters. Therefore, it was objective to modify the method of Heesen et al., (1976) for the preparation of sucrose emulsifiers (solvent-free reaction) by replacing the expensive polyalcohols for the cheaper sucrose which constitutes the hydrophilic portion of the nonionic surfactant. The products were evaluated for the hydrophile-lipophile balance (HLB), surface and interfacial tension properties as well as emulsion stability.

\section{MATERIALS AND METHODS}

\subsection{Materials}

Pure sucrose was supplied by Sugar and Intergrated Industries Company (Egypt). All fatty acids, solvents and chemicals are high purity grade (BDH, England, and MERCK, Germany).

\subsection{Methods}

\section{Preparation of sucrose esters (SE)}

Sucrose esters having different fatty acid moieties were prepared according to the method of Heesen et al., (1976) replacing polyalcohols with sucrose as a modification of this method. Equimolecular amounts of pure sucrose and fatty acids (lauric, palmitic and oleic) were reacted together in presence of the in situ prepared sodium soap (catalyst) amounting to $20 \%$ of the total weight of sucrose. The mixture was heated at $100{ }^{\circ} \mathrm{C}$ under nitrogen while the constituents had melted. The temperature was increased to $130^{\circ} \mathrm{C}$ under reduced pressure $(40 \mathrm{~mm} \mathrm{Hg})$ for 16 hours with continuos stirring. The reaction products were dissolved in an equal quantity of warm 
butanone and the soap was acidified with 3-5 parts by weight of lactic acid per 100 parts of reaction product. The non-esterified sucrose and excess of lactic acid were then eliminated by two successive extractions with distilled water at $70^{\circ} \mathrm{C}$. The solvent was then removed under reduced pressure to obtain the final sucrose esters.

\section{Analysis of the sucrose esters}

\section{1) Purity}

The purity of sucrose esters was calculated from the saponification and ester values of the product as follows:

$$
\text { Purity } \%=\frac{\text { Ester value }}{\text { Saponification value }} \times 100
$$

Ester value is obtained by subtracting acid value of the product from its saponification value.

\section{2) Hydrophile-lipophile balance (HLB)}

Hydrophile-lipophile balance of sucrose esters were calculated using the following equation of Griffin (1965):

$$
H L B=20\left(1-\frac{\text { Saponification value }}{\text { Acid value }}\right)
$$

\section{3) Surface and interfacial tension}

Surface and interfacial tension of sucrose esters were measured according to the methods of Alexander and Hayter (1971) using CSC-DuNouy Interfacial Tensiometer Model 70545 (CSC Scientific Company, Fairfrax, VA).

\section{4) Emulsion stability}

The ability of sucrose ester emulsifiers to stabilize oil-in-water $(\mathrm{O} / \mathrm{W})$ and water-in-oil $(\mathrm{W} / \mathrm{O})$ food emulsions were measured according to the method of Akoh (1992), using emulsifiers at $0.5 \%$ concentrations and emulsion stability was measured after $0,2,4,8,12,24$ and 48 hours at room temperature $\left(25^{\circ} \mathrm{C}\right)$ for $\mathrm{O} / \mathrm{W}$ and at refrigeration temperature $\left(4^{\circ} \mathrm{C}\right)$ for $\mathrm{W} / \mathrm{O}$ emulsions. Appropriate controls with no emulsifier were used.

All results are the mean of two concordant values; otherwise two other replications were tried to achieve higher accuracy.

\section{RESULTS AND DISCUSSION}

Purity, surface tension, interfacial tension and hydrophile-lipophile balance (HLB) are recorded in Table I. The purity of the product generally complies with the purity of most of commercial emulsifiers (Heesen et al., 1976; Rizzi and Taylor, 1978). The results also indicated that surface tension of sucrose laurate and palmitate were almost the same value (52.8 and 53.2 dynes $/ \mathrm{cm}^{3}$, respectively), however, sucrose oleate exhibited lower surface tension $(40.2$ dynes $/ \mathrm{cm}^{3}$ ). Conversely, interfacial tension of sucrose oleate gave an anomalous value of 21.4 dynes $/ \mathrm{cm}^{3}$. This result could be attributed to the presence of unsaturated fatty acid moieties (oleic) and the hydrophilic carbohydrate backbone in the carbohydrate polyesters (Akoh, 1992; Akoh and Nwosu, 1992; Cornec et al., 1996). With reference to the HLB values, sucrose laurate and palmitate showed HLB value of 8.2 and 6.8 , respectively, however the sucrose oleate showed HLB value of 3.6. The differences in HLB values can be attributed to the difference in fatty acid chain lengths (Ebeler and Walker, 1984). On the other side, HLB value of sucrose oleate is a good indication for its potential use as W/O emulsion, while, on the other hand HLB values of sucrose laurate and palmitate revealed their capacity to stabilize O/W emulsions (Akoh and Nwosu, 1992).

\section{Table I}

\section{Purity and surface active properties of the}

\begin{tabular}{|c|c|c|c|c|}
\hline Emulsifier & $\begin{array}{l}\text { Purity * } \\
(\%)\end{array}$ & $\begin{array}{l}\text { Surface tension } \\
\left(\text { dynes } / \mathrm{cm}^{3}\right)\end{array}$ & $\begin{array}{l}\text { Interfacial tension } \\
\left.\text { (dynes } / \mathrm{cm}^{3}\right)\end{array}$ & HLB** \\
\hline Sucrose laurate & 86.5 & 52.8 & 8.2 & 8.2 \\
\hline Sucrose palmitate & 87.3 & 53.2 & 8.4 & 6.8 \\
\hline Sucrose oleate & 88.6 & 40.2 & 21.4 & 3.6 \\
\hline
\end{tabular}
prepared sucrose fatty acid esters

* Purity $\%=($ Ester value/Saponification value $) \times 100$

** HLB $=20$ [1- (Saponification value/Acid value)]

Operationally a stable emulsion is one that is very slow to undergo the various processes which result in the separation of oil and water phases. In addition $\mathrm{O} / \mathrm{W}$ and $\mathrm{W} / \mathrm{O}$ emulsion stability is illustrated in Figures (1 and 2) showing that sucrose laurate and palmitate have high ON emulsion stability $(30 \%$ and $40 \%$ emulsion separation, respectively) after 12 hours. While, sucrose oleate on the other hand exhibits low O/W emulsion stability $(90 \%$ emulsion separation) after the same period. Conversaly, W/O emulsion, stabilized by sucrose oleate has more stability (less emulsion separation) after 12 hours, however, sucrose laurate and palmitate give less stability (more emulsion separation). It is known that 
HLB value of an emulsifier determines the emulsion type (W/O or W/O) that tend to be formed, whereas low HLB values (ranging from 3 to 6 ) will promote or stabilize W/O emulsion, while intermediate values (ranging from 8 to 13) can stabilize $O / W$ emulsion (Griffin, 1965; Akoh and Nwosu, 1992; Partal et al., 1997).

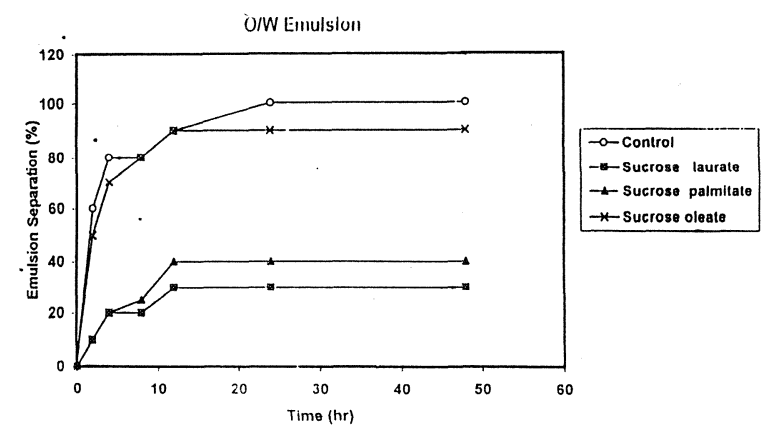

Figure 1

Stability $O / W$ emulsions as a function of time at room temperature $\left(25^{\circ} \mathrm{C}\right)$. A $0.5 \%$ emulsifier concentration was used. Control no emulsifier

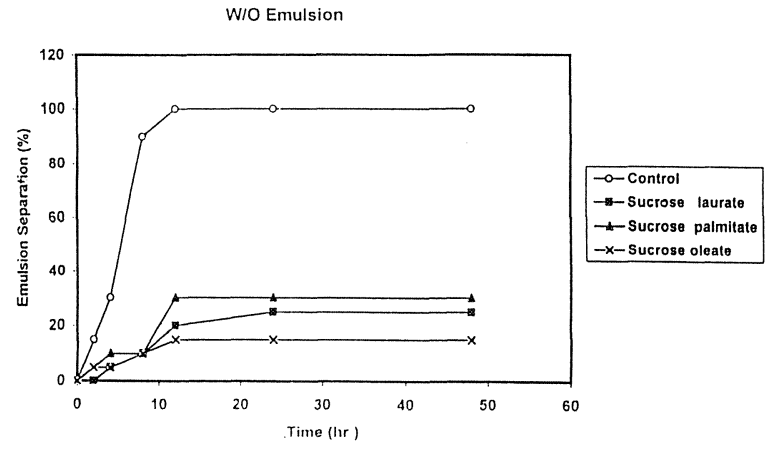

Figure 2

Stability $O / W$ emulsions as a function of time at refrigeration temperature $\left(4^{\circ} \mathrm{C}\right)$. A $0.5 \%$ emulsifier concentration was used. Control no emulsifier

Generally, sucrose esters of fatty acids are more safe than those of polyalcohol derivatives since the sucrose esters give no toxic anhydro compounds (Heesen et al., 1976). In addition, the physiological properties of the sucrose esters are unique, since they are nontoxic, odorless and tasteless. When sucrose esters are ingested, they are hydrolyzed to form normal food products (Osipow et al., 1957; Calahorro et al., 1992).

\section{ACKNOWLEDGMENTS}

The author wishes to thank Prof. Dr. M. Hassan El-Mallah, Fats \& Oils Res. Lab., NRC, Cairo, Egypt for his valuable advice and helpful discussions during writing this work.

\section{REFERENCES}

1. Akoh, C.C. (1992).-- -Emulsification properties of polyesters and sucrose ester blends I. Carbohydrate fatty acid polyesters".-J. Am. Oil Chemists'Soc. 69, 9-13.

2. Akoh, C.C. and Nwosu, C.V. (1992).- «Emulsification properties of polyesters and sucrose esters blend II. Alkyl glycoside polyesters". -J. Am. Oil Chemists'Soc. 69, 14-19.

3. Akoh, C.C.; Swanson, B.G. (1987).- -One-stage synthesis of raffinose fatty acid polyesters".-J. Am. Oil Chemists'Soc. 52, 1570-1576.

4. Akoh, C.C. and Swanson, B.G. (1989).-— - Preparation of trehalose and sorbitol fatty acid polyesters".- J. Am. Oil Chemists'Soc. 66, 1581-1587.

5. Alexander, A.E. and Hayter, J.B. (1971)._- «Physical Methods of Chemistry".-Published by: John Wiley \& Sons, New York, U.S.A.

6. Bobalek, E.G. (1977).- « Prospects and potential for commercial production and utilization of sucrose fatty acid esters".- In Sucrochemistry, R.E. Gould Ed., p. 162. American Chemical Society, Washington, DC.

7. Calahorro, C.; Muñoz, J.; Berjano, M.; Guerrero, A and Gallegos, C. (1992).- «Flow behavior of sucrose stearate/water systems".-J. Am. Oil Chemists'Soc. 69, 660-666.

8. Cornec, M.; MacKie, A.R.; Wilde, P.J. and Clark, D.C. (1996). - «Competitive adsorption of $\beta$-lactoglobulin and $\beta$-casein with Span 80 at the oil-water interface and the effect on emulsion behaviour».-J. Colloids Surfaces, 114, 237-244.

9. Ebeler, S.E. and Walker, C.E. (1984).-«Effect of various sucrose fatty acid ester emulsifiers on high-ratio white layer cakes".-J. Food Sci. 49, 380-388.

10. Griffin, W.C. (1965)._-Emulsions in: Encyclopedia of Chemical Technology».-Vol. 8: 117-154, Interscience Publishers, New York, London, Sydney.

11. Heesen, J.G.; Kuipers, P.K. and Velthuijsen, J.A (1976). - «Methods for the preparation of esters of polyalcohols".-U.K. Patent n. ${ }^{\circ} 1.457 .569$ (8.12.76).

12. Osipow, L.; Snell, F.D. and Finchler, A. (1957).«Sugar esters".J. Am. Oil Chemists'Soc. 34, 185-188.

13. Partal, P.; Guerrero, A.; Berjano, M. and Gallegos, C. (1997).- «Influence of concentration and temperature on the flow behaviour of oil-in-water emulsions stabilized by sucrose palmitate».-J. Am. Oil Chemists'Soc. 74, 1203-1212.

14. Rizzi, G.P. and Taylor, H.M. (1978).- «A solvent-free synthesis of sucrose polyesters".-J. Am. Oil Chemists'Soc. 55, 398-401.

15. Weiss, T.J.; Brown, M.; Zeringue, H.J. and Feuge, R.O. (1971). - «Quantitative estimation of sucrose esters of palmitic acid".-J. Am. Oil Chemists'Soc. 48, 145-149.

16. Weiss, T.J.; Brown, M.; Zeringue, H.J. and Feuge, R.O (1972). - «Influence of solvent on degree of acylation in the formation of sucrose esters".-J. Am. Oil Chemists'Soc. 49, 524-529. 